This is the author's accepted version of an article published as: Torrigiani F, Pierini A, Lowe R, Simcic P, Lubas G. Soft tissue sarcoma in dogs: A treatment review and a novel approach using electrochemotherapy in a case series. Vet Comp Oncol. 2019;1-8.

Link to the version of record: https://doi.org/10.1111/vco.12462

\title{
Soft tissue sarcoma in dogs: A treatment review and a novel approach using electrochemotherapy in a case series
}

Filippo Torrigiani, Alessio Pierini, Ron Lowe, Petra Simčič, George Lubas

\begin{abstract}
Canine soft tissue sarcomas (STSs) are locally invasive mesenchymal neoplasms.

Electrochemotherapy (ECT) is an antitumour local ablative treatment that uses electric pulses to enhance the intracellular delivery of cytotoxic drugs. The aim of this retrospective study was to review the current treatment for STSs and to evaluate the efficacy and safety of ECT with bleomycin in canine STSs. Fifty-two dogs with 54 STSs were included. Three groups were arranged: (a) ECT alone, (b) intra-operative ECT and (c) adjuvant ECT. Signalment, tumour size, location, histological grade and margins and ECT parameters were collected. Recurrence rate (RR) and disease-free interval (DFI) were calculated. Treatment toxicity was assessed using a 6-point scale. STSs were mostly located on limbs $(77.8 \%)$. Median tumour size was $4.3 \mathrm{~cm}$ (range $0.4-17.0$ $\mathrm{cm})$. Most STSs were grade I (47.7\%) and II (50.0\%), and histological margins were incomplete in $94.5 \%$ of cases. Two complete remissions, one partial remission and one stable disease were recorded in group 1. Group 2 and 3 were similar for tumour location, size and grade, histological margins, treatment toxicity, pulse frequency and voltage. Moreover, RR and DFI were similar between group 2 and 3 (23\% and 25\%, 81.5 and 243 days, respectively). Local toxicity post ECT was mild (score $\leq 2$ ) in $66.7 \%$ of cases. Higher toxicity score was associated with higher pulse voltage $(1200 \mathrm{vs} 1000 \mathrm{~V} / \mathrm{cm})(P=0.0473)$. ECT coupled with bleomycin resulted safe and efficient in tumour local control and should be considered as an option for treatment of canine STSs.
\end{abstract}

\section{Introduction}

Soft tissue sarcomas (STSs) are a heterogeneous population of mesenchymal neoplasms with variable histogenesis and represent up to $15 \%$ of all cutaneous and subcutaneous tumours in dogs. ${ }^{1}$ Middle-aged to older dogs are more commonly affected, and large breed dogs tend to be overrepresented. ${ }^{1,2}$ Up to $60 \%$ of canine STSs are found on limbs, while other anatomical localizations are less frequently represented (trunk $35 \%$ and head or neck 5\%). ${ }^{1,3-5}$ Most STSs are locally aggressive and tend to grow between fascial planes thus resulting in locally invasion. Furthermore, STSs can be surrounded by a pseudocapsule, tissue resembling a capsule formed by the compression of peritumoral connective tissue that may contain or be confluent with tumour cells. ${ }^{2,6}$ The classification of these tumours in dogs is controversial and has been reviewed several 
times. Nowadays, the term STS includes the following: fibrosarcoma, non-plexus-derived peripheral nerve sheath tumour, canine perivascular wall tumour, myxosarcoma, malignant mesenchymoma, liposarcoma and undifferentiated sarcoma. ${ }^{1,2,5,7}$ A three-tier histological grading has been developed for canine STSs since the late 1980s and reviewed recently. ${ }^{2,8}$ Grade I (lowgrade) STSs are the most frequent form and are usually slow growing lesions with the lowest recurrence rate (RR) after surgical excision. Higher tumour grade has been associated with a more aggressive biological behaviour resulting in higher local RR.2 McSporran (2009) reported that about $7 \%$ of low-grade tumours recurred after marginal excision compared with $34 \%$ and $75 \%$ for intermediate- and high-grade tumours, respectively. ${ }^{9}$ The metastatic potential of canine STS is poorly described. They are usually considered to have low to moderate metastatic rate with a positive association with histological grade and mitotic index. ${ }^{2}$ Several authors have described metastatic rates ranging from $1.7 \%$ to $41 \%$; however, the changes made in classification and treatment of these neoplasms probably explain variability of these data. ${ }^{10-16}$ Given the low metastatic potential, but the invasiveness of surrounding tissues, the main concern when treating STS is local tumour recurrence.

The standard treatment for canine STSs is the surgical excision with wide margins (minimum of 3 $\mathrm{cm}$ for lateral margins and one clean fascial plane for deep margins), ${ }^{1,5}$ even though other surgical protocols have been proposed..$^{3,5,17-20}$ The degree of resection and completeness of the surgical margins are important prognostic factors. ${ }^{2}$ Treatment protocols that combine surgery with adjuvant therapies such as radiation therapy, metronomic chemotherapy and intralesional chemotherapy have been proposed. A summary with particular focus on the treatment approach, histological grade and margins of STSs, and the outcome (particularly RRs and disease-free interval [DFI] when available) is reported in Table 1.

The data presented in Table 1 are difficult to interpret comparatively because of the high variability in surgical and/or adjunctive therapy used and the differences in the number of patients, tumour grade and histological margins. The size of tumours differs significantly among the studies and must be considered although it has not been identified as a prognostic factor. ${ }^{2}$ Nevertheless, tumour size can be important when considering the surgical approach, as historically tumour larger than 5 $\mathrm{cm}$ of diameter have been considered to have shorter DFIs in both human and canine literature. ${ }^{5}$ Some studies also included histotypes, which are not considered STSs anymore (eg, hemangiosarcoma, malignant fibrous histiocytoma, rhabdomyosarcoma). Another variable is tumour site, some studies included oral STS (generally they are not included in the conventional canine STSs grouping) and there is a different number of cases of STSs affecting limbs, a location where wide surgical margins are often difficult to obtain. Treatment side effects must also be considered: complications in wound healing were reported when radical surgery was applied on distal limbs, systemic side effects were reported in dogs treated with metronomic chemotherapy and local side effects after radiation therapy or intralesional chemotherapy were observed when applied on a surgical wound. Finally, some of the studies included cases that had previous surgical excision (which is a potential negative prognostic factor according to Dennis et al). ${ }^{2}$

Recently, Cancedda et al studied a protocol with radiotherapy alone as palliative treatment on macroscopic STSs with good results on progression free interval (median 419 days) and overall survival (median 513 days). In the same study the addition of post-radiation metronomic chemotherapy (using a combination of thalidomide, piroxicam and cyclophosphamide) did not improve the progression-free interval or the overall survival. ${ }^{26}$ 
Electrochemotherapy (ECT) is a local ablative technique for the treatment of locally invasive cutaneous primary and secondary tumours that uses electric pulses to enhance the transmembrane delivery of cytotoxic drugs. The procedure consists of applying short high-intensity pulsed electric fields to cells, in response to which, the plasma membrane permeability to various molecules transiently increases. This facilitates cellular uptake of, cytotoxic agents, thus increasing their cytotoxicity. ${ }^{27,28}$

Two main cytotoxic agents are used in combination with ECT: bleomycin which is administered either intratumorally (IT) or intravenously (IV) and cisplatin used only IT.

Bleomycin is a non-permeable antitumor antibiotic that causes single-strand and double-strand breaks in DNA, chromosomal aberrations, gaps, fragments and translocations. ${ }^{29}$ Bleomycin is considered a non-permeant cytotoxic drug, so its use as a single agent is very limited nowadays. Recent studies in veterinary oncology reported the use of intralesional bleomycin for the treatment of acanthomatous ameloblastoma in $\operatorname{dogs}^{30}$ and as a component in a multimodal approach for the treatment of unresectable head and neck squamous cell carcinoma in cats. ${ }^{31}$

The increase cellular uptake of bleomycin in cells exposed to an electric field causes a potentiation of its cytotoxicity that ranges from 100- to 5000-fold in vitro depending on the studies. The in vitro data were confirmed in vivo in different animal models and later in clinical studies. ${ }^{27,28,32}$

Moreover, bleomycin has a role in what has been defined the vascular disrupting effect of ECT selectively killing endothelial cells of tumour vessels. ${ }^{33,34}$ Finally, ECT with bleomycin has been recently found to induce evidence of immunogenic cell death in a murine model, suggesting its role in the host immune response against the tumour. ${ }^{35}$

ECT with either bleomycin or cisplatin has been proven safe and effective on many canine neoplasms such as mast cell tumour ${ }^{36-38}$ and perianal tumours ${ }^{39}$ and has also been coupled with gene-electrotransfer with interleukin-12 in the treatment of canine mast cell tumour. ${ }^{40}$ The operating procedure for ECT in dogs and cats has been published recently as a visualized paper. ${ }^{41}$

ECT coupled with either bleomycin or cisplatin has been also applied in cats with good results especially in the treatment of squamous cell carcinomas of the head and as adjuvant treatment for incompletely excised fibrosarcoma. ${ }^{42-44}$ In addition, the application of ECT intraoperative vs postoperative in feline STS has been also reported. ${ }^{45}$ ECT with intralesional cisplatin has been proven effective and safe for the treatment of equine cutaneous sarcoids, used either as single or adjuvant treatment depending on the studies. ${ }^{46,47}$ Finally, ECT has also been reported for the treatment of miscellaneous tumours in exotic species (ie, ferret and pet rats) with promising results. ${ }^{48,49}$

To the best of our knowledge, there are only two papers that investigated ECT on canine sarcomas. ${ }^{50,51}$ In the former, 22 dogs with incompletely excised high-grade sarcomas were treated with bleomycin administered in the tumour bed followed by application of biphasic electric pulses. The overall response rate was $95 \%$ with median time to recurrence of 730 days. However, the lack of information regarding the type of surgery and tumour grading with the enrolment of currently non-classified STSs (eg, leiomyosarcoma, malignant fibrous histiocytoma, hemangiosarcoma) makes results about efficacy of ECT difficult to interpret. ${ }^{50}$ In the latter, the same authors published a case report of a grade III STS in a dog treated with neoadju vant ECT followed by marginal surgery and intraoperative ECT with excellent results regarding cosmetic and functional results as well as survival time. ${ }^{51}$ 
The purpose of this retrospective study was to evaluate the efficacy and safety of ECT coupled with intravenous bleomycin in the treatment of STSs in a series of dogs.

\section{Materials and methods}

Medical records of dogs with STSs treated with ECT from December 2004 to December 2016 were collected retrospectively.

The owners elected to carry out ECT as an alternative treatment to surgery and/or radiotherapy. An informed consent was obtained from the owners.

For all dogs, the diagnosis of STS was based on histopathology. All dogs were staged with physical examination, fine needle aspiration of regional lymph node (if palpable) and three view thoracic radiographs. Complete blood cell count, minimal serum biochemistry, coagulation profile and urinalysis were performed as all patients underwent general anaesthesia. For ECT treatment, dogs were premedicated with medetomidine and butorphanol. Once sedated, patients were preoxygenated via a face mask, and anaesthesia was induced with intravenous administered alfaxalone. Dogs were then intubated, and anaesthesia was maintained with a mixture of oxygen, nitrous oxide and isoflurane. Atipamezole was then administered to reverse medetomidine at the conclusion of the procedure and all patients were discharged within 8 to 12 hours from the procedure.

Bleomycin was diluted in saline solution and administered IV at a dosage of $15000 \mathrm{IU} / \mathrm{m} 2$ (European Pharmacopoeia). Treatment areas were prepared as for surgery, skin was clipped and aseptically prepared with povidone-iodine wash (10\% iodine) and surgical spirit. All dogs received anti-inflammatory and pain relief treatment in the peri-operatory period with meloxicam.

The ECT was performed using two pulse generators: Cytopulse PA4000 and Cytopulse Oncovet (both from Cyto Pulse Sciences, Inc., Holliston), with type II needle electrodes. ${ }^{52}$ More specifically the needle pattern consisted in two parallel rows of 1 to $1.5 \mathrm{~cm}$ needles (six needles for each row), the rows being $6 \mathrm{~mm}$ apart. The pulse pattern employed was eight monophasic square pulses of 100 microseconds each at a frequency of $1 \mathrm{~Hz}$ with the PA4000, and 1 or $5 \mathrm{kHz}$ with the Oncovet. The pulse amplitude to electric distance ratio was 1000 or $1200 \mathrm{~V} / \mathrm{cm}$. The time between bleomycin injection and pulse delivery was 8 minutes, with a therapeutic window for electroporation of 20 minutes. After ECT treatment all patients received antibiotic cover (amoxicillin and clavulanic acid or clindamycin, standard dosages) for at least 1 week. Patients were assessed every 3 to 10 days for the initial 4 weeks after ECT treatment, then monthly for 3 months. Thereafter, patients were monitored at regular intervals either by direct examination or by telephone contact with the owner.

The progression of changes in the treated area was recorded by digital camera images.

Patients were divided into three groups according to the ECT modality applied at the first treatment. Group 1: ECT alone, performed on macroscopic disease, when owners declined surgery. In this case, the tumour plus a 1-2 cm margin in all planes into grossly normal tissue were accessed by penetration of the electrode needles. The treatment was started in the margins and progressed concentrically into the tumour mass. Group 2: intraoperative ECT, performed at the same time of the surgical cyto-reduction of the tumour. During surgery the majority of the tumour was excised (debulking surgery), with no attempt to obtain complete margins, and ECT was applied to 1 to $2 \mathrm{~cm}$ laterally to the margins and into deep margin before surgical wound closure. Group 3: adjuvant ECT, applied when the surgical resection of the tumour had been performed attempting wide 
margins, and the report of the histological examination showed incomplete excision. Therefore, according with the owner consent the ECT was arranged. The ECT treatment area was extended at least $1.5 \mathrm{~cm}$ from the healed surgical scar site in all planes (see Supporting Information Figures S1S17).

From the medical records, the following information was collected: signalment, tumour size and location, histological grade, completeness of histological margins, electroporation parameters and ECT modality. All tumours were staged according to the modified staging system for canine STS. ${ }^{1}$

In addition, the following parameters were calculated: RR and DFI. The response for patients in group 1 was evaluated according to the response evaluation criteria for solid tumours as follows: complete remission (CR) was defined as total reduction of the tumour; partial remission (PR) was defined as $\geq 30 \%$ reduction in tumour diameter; stable disease (SD) was defined as $<30 \%$ reduction in tumour diameter or $<20 \%$ increase in tumour diameter; and progressive disease (PD) was defined as $\geq 20 \%$ increase in tumour diameter. Presence of new lesions near to the primary tumour or presences of metastasis were considered as PD. ${ }^{53}$

In order to assess the local treatment toxicity a previously published grading score (5-point scale) for tissue necrosis was used as follow: $0=$ none, $1=$ slight swelling, $2=$ swelling $/$ necrosis $<1 \mathrm{~cm}$, $3=$ severe swelling, $4=$ deep necrosis and $5=$ severe swelling and tissue loss (see Supporting Information Figures S1-S17). ${ }^{38}$

DFI was calculated from the date of treatment with ECT to the first suspected or confirmed local tumour recurrence or death of the animal unrelated to the tumour; or alternatively the DFI was censored at the time we prepared this article.

The statistical software GraphPad Prism version 6.00 (GraphPad Software, La Jolla, California) was used for statistical analysis. Group 1 data were analysed only with descriptive statistics and were censored from other statistical analysis because the small number of cases. Categorical data were assessed using $\chi 2$ test or Fisher's exact test. Comparison between group 2 and 3 for continuous variables (size, follow-up, DFI) were analysed using Mann-Whitney test or $\mathrm{t}$ test. A P-value $<0.05$ was considered significant.

\section{Results}

Fifty-two client-owned dogs with 54 STSs were enrolled in the study. Twenty-two were females (16 neutered), and 30 were males (14 neutered). The majority of dogs were pure breeds (38/52, $73.1 \%$ ); Labrador retrievers ${ }^{8}$ and Staffordshire bull terriers ${ }^{5}$ were overrepresented. Patient age ranged from 4 to 15 years (median 9.1).

Most of the tumours were located in the limbs (42/54, 77.8\%), and other locations were trunk (7/54, $13.0 \%$ ) and head $(5 / 54,9.2 \%)$. Tumour size ranged from 0.4 to $17.0 \mathrm{~cm}$ (median $4.3 \mathrm{~cm}$ ), median size of STSs affecting the limbs was $4.5 \mathrm{~cm}$. Regional lymph nodes involvement and distant metastasis were not detected, and all tumours were considered N0 and M0. There were $18 \mathrm{~T} 1 \mathrm{a}, 10$ T1b, 13 T2a and 13 T2b. In the light of these data tumour were staged as follows: 43 stage 1, 1 stage 2; staging was not feasible for 10 cases as histologic grade was not available. Tumour grading was available in 44 cases, most tumours were grade I $(21 / 44,47.7 \%)$ and II $(22 / 44,50.0 \%)$, only one was grade III (2.3\%). Histological evaluation of surgical margins was available in 37 cases $(37 / 50,74 \%$ of dogs that underwent adjuvant ECT), and the majority $(35 / 37,94.5 \%)$ had 
incomplete margins with only $2 / 37$ cases $(5.5 \%)$ having histological margins free of neoplastic cells (Table 2).

Four STSs were enrolled in group 1, 26 in group 2 and 24 in group 3. Median time from surgery and adjuvant ECT (group 3) was 17 days (range 12-51 days).

Nine out of 54 STSs $(16.7 \%)$ were treated with Cytopulse PA4000 and received pulses at a frequency of $1 \mathrm{~Hz}$. The remaining $45(83.3 \%)$ were treated with Cytopulse Oncovet, of these, 10 received pulses at a frequency of $1 \mathrm{~Hz}$ and 35 at $5000 \mathrm{~Hz}$. Twenty-seven out of $54(50.0 \%) \mathrm{STSs}$ were treated using an amplitude to electric distance ratio of $1000 \mathrm{~V} / \mathrm{cm}$ and $27 / 54(50.0 \%)$ with $1200 \mathrm{~V} / \mathrm{cm}$ (Table 3).

Group 2 and 3 were compared for homogeneity and did not show any statistical differences for the following parameters: tumour location, size and grade, histological margins, pulse frequency and voltage, treatment toxicity, RR, follow-up time and DFI.

The treatment response in group 1 was as follows: two CR, one PR and one SD, with an overall response rate (ORR) of 75\%. Both dogs that obtained CR died with no tumour 367 and 1389 days after ECT treatment. The dog with SD had a local recurrence after 41 days. The dog underwent a marginal surgery and a second ECT treatment (intraoperative) and died without any tumour 2442 days later. The dog with PR had a first local recurrence after 15 days from the first treatment, then the patient underwent a second ECT with no response and then a marginal surgery and a third ECT treatment (as adjuvant) and died 837 days after diagnosis with no local recurrence.

All animals received at least one ECT treatment. Five STSs $(9,3 \%)$ were treated twice. Four out of five STSs that needed a second treatment had a second local tumour recurrence. Three STSs underwent a third treatment and one dog developed a third recurrence. Median time between the first and the second ECT treatment (five cases) was 68 days (range 14-495 days). Median time between the second and the third ECT treatment (three cases) was 82 days (range 27-614 days).

Median follow-up for all dogs was 498 days (range 8-2483 days). At the end of the observation period, twenty-one dogs had died; of these, six had tumour recurrence, which was the reason for euthanasia in one case. Of the other 29 dogs alive, eight had tumour recurrence and in three cases the affected limb was amputated as rescue treatment. Patient outcome was not available in two cases. Overall tumour RR in groups 2 and 3 was 24.0\% (12/50) (Table 4).

RR was not associated with tumour grade, anatomical site, tumour size, pulse frequency and pulse voltage.

For all dogs, median DFI was not reached. For dogs with tumour recurrence, median DFI was 81.5 days (range 15-1025). Median DFI for the second and the third ECT treatment was 348 days (range 24-2442) and 101 days (range 73-129), respectively.

Toxicity grades were distributed as follows: 7 (12.9\%) score $1 ; 12(22.2 \%)$ score $2 ; 11(20.4 \%)$ score $3 ; 5(9.3 \%)$ score 4 and $2(3.7 \%)$ score 5. Seventeen $(31.5 \%)$ treated tumours showed no local toxicity (score 0) (see Supporting Information Figures S1-S17). The treatment was overall well tolerated, local toxicity was mild in $66.7 \%$ of cases $(36 / 54$, with toxicity score $\leq 2)$, and was not associated with tumour grade and size and pulse frequency. Treatment toxicity score was associated with higher amplitude to electric distance ratio $(1200 \mathrm{vs} 1000 \mathrm{~V} / \mathrm{cm})(\mathrm{P}=0.0473)($ Table 5). 


\section{Discussion}

Currently, wide margin surgery is considered the best choice to treat canine STSs. ${ }^{5}$ However, most STSs affect limbs and extremities making this option a challenge. The present study reviewed the efficacy and toxicity of ECT coupled with bleomycin in treatment of STSs in dogs.

In our study, 52 dogs with 54 histologically diagnosed STSs were included. Tumours were more commonly located at the limbs $(76.4 \%)$ consistent with published literature. ${ }^{16,18,19,25}$ Median tumour size was $4.3 \mathrm{~cm}$ (range $0.4-17 \mathrm{~cm}$ ). Tumour size has not been recognized as a prognostic factor for tumour recurrence and overall survival in canine STSs when systematically reviewed. ${ }^{2}$ Nevertheless, bigger tumours ( $\geq 5 \mathrm{~cm}$ of diameter) are often difficult to excise with wide margins especially when located on areas such as limbs (in our study the median size of tumours affecting the limbs was $4.5 \mathrm{~cm}$ ). Moreover, tumours $\geq 5 \mathrm{~cm}$ have been historically considered to have shorter DFI in both human and canine literature. 5 Information about tumour grade was available in 44 cases, with most tumours being grade I and II (47.7\% and 50.0\%, respectively), and only one case of grade III STS (2.2\%). These findings agree with previous literature, in which low- and intermediate-grade STSs are reported to be more frequent. ${ }^{2,9,19,25}$

ECT was used as the sole therapy in four dogs, and the treatment responses were two CR, one PR and one SD. Then, when ECT alone was used as a second treatment, the two dogs treated responded with PR. To our knowledge, this was the first time that ECT was used alone in the treatment of canine STSs and, although our sample is too small to draw any definitive conclusion, we observed an overall response rate of $75 \%$ which is an encouraging result considering that STSs are usually considered chemoresistant. ${ }^{1}$

The overall tumour RR of ECT used in combination with surgery (intraoperative or adjuvant beside post-operative) was $24.0 \%$ similar to historical data reported for treatment of STS with surgery alone $(27.9 \%) .{ }^{21}$ Surgical re-excision of incomplete resected STSs resulted in $15 \%$ of local tumour recurrence. ${ }^{13}$ When surgery was coupled with radiotherapy, lower tumour RR was observed $(18.0 \%) .{ }^{16}$ When orthovoltage radiation therapy was coupled with low-dose doxorubicin (used as radiosensitizer) on microscopic disease similar RR was observed (18\%). ${ }^{14}$ Cisplatin-based local chemotherapy (either cisplatin biodegradable implants or cisplatin impregnated beads) has been applied as adjuvant treatment to marginal or incomplete surgery; however, data on local tumour RR differ between the two published studies $\left(16.6 \%,{ }^{22} 29 \%{ }^{24}\right)$. The comparison between these results should be evaluated with caution due to the heterogeneity of the populations included. More precisely, the data of the completeness of histological margins should be carefully taken into account as it has been recognized as the most important prognostic factor for local tumour recurrence together with histological grade. Prpich et al ${ }^{19}$ observed a RR of $3.2 \%$ when using radical surgery and second intention healing and in their study, margins were complete in $100 \%$ of cases, highlighting the importance of first line local tumour control with surgery in canine STSs. On the other hand, Elmslie et al reported a 100\% of local tumour RR in their control group of dogs with incompletely excised STSs, which had not been treated with metronomic chemotherapy. In this latter study, even if the RR of the group treated with metronomic chemotherapy was not specified, the DFI was statistically higher in the treated group when compared to the control group. ${ }^{23}$ Stefanello et a ${ }^{18}$ using marginal surgery on low-grade STSs obtained a RR of $10.8 \%$, and only $34.2 \%$ of histological margins were reported as incomplete. McSporran (2009) observed RRs of 0\% and $23 \%$ when STSs were completely or marginally excised respectively and, in his study, margins were reported as clean in $100 \%$ of cases (more specifically, $76 \%$ clean, $24 \%$ clean but close). ${ }^{9}$ Chase et $\mathrm{al}^{21}$ observed a RR of $27.9 \%$ when STSs were treated with surgery alone; however, data on 
histologic margins were largely unreported (48.1\%). Demetriou et al ${ }^{16}$ obtained excellent results when coupling radiation therapy with marginal surgery, as only $18 \%$ of STSs recurred locally even if all margins resulted incomplete on histopathology.

ECT has been previously applied as adjuvant treatment for incompletely excised high-grade canine sarcomas. ${ }^{50}$ However, the different inclusion criteria and the lack of information about surgical technique and tumour grading make the results of the two studies impossible to compare.

In our study, histological margins information was available in 37/50 cases of STSs treated with adjuvant ECT coupled with bleomycin (group 2 and 3), and $94.5 \%$ had incomplete margins. For the high rate of incomplete margins, the RR observed in the presented study is very promising if compared with RR obtained with marginal surgery alone.

Moreover, tumour size and location can represent a bias when analysing the data of local recurrence, because, although they are not considered prognostic factors for tumour relapse, they affect the feasibility of first-line curative-intent surgery. In our study, median tumour size was 4.3 $\mathrm{cm}$, a number close to the cut-off of $5 \mathrm{~cm}$ traditionally considered to have shorter DFI in both human and canine literature. ${ }^{5}$

Interestingly, in our caseload, repeated treatments on recurred tumours obtained longer median DFI when compared with the first treatment, namely 348 and 101 days for second and third treatment, respectively. Repeated ECT treatments are a well-established practice in human patients with good results on various tumour histotypes ${ }^{27,28,54}$ and, although our sample is too small to draw any conclusion, with slow-growing tumours, such as low-grade canine STSs, multiple ECT treatment can potentially obtain even better results regarding local disease control and DFI.

ECT coupled with intravenous bleomycin was well tolerated without any systemic side effect and locally showing only low toxicity in most cases. Using a previously published scale, we scored local treatment toxicity. ${ }^{38}$ Local toxicity was overall well tolerated, with $66.7 \%$ of dogs having a toxicity score $\leq 2$. Local side effects were self-limiting in all dogs and managed only medically when needed. In the study, about ECT in canine mast cell tumour, Lowe et $\mathrm{al}^{38}$ recorded $53 \%$ of mild local toxicity (score $\leq 2$ ). The difference between this and our result can be explained by the different behaviour of the two tumour histotypes. Indeed, mast cell tumours are more prone to cause inflammation of the peritumoral tissues and local treatment side effects can be negatively affected. Treatment side effects (eg, delays in wound closure, pathological fracture, wound dehiscence, local ulceration, need for ancillary treatments and so on) have been reported in the other studies that used radical surgical approach or adjuvant treatments for canine STSs (ie, radiation therapy and intralesional chemotherapy), and should be taken into account when evaluating the risk/benefit ratio of a treatment. ${ }^{16,19,22,24}$

It should be noticed that in our study higher local treatment toxicity was associated with higher amplitude to electric distance ratio (1200 vs $1000 \mathrm{~V} / \mathrm{cm})$. This finding has never been reported neither in human nor in veterinary literature and probably needs to be carefully considered given the subjectivity nature of the toxicity scale.

The limitations of the present study are linked to its retrospective nature and to the long period of case collection. Furthermore, two different machines with different ECT parameters were used in this study, even if, when analysed compared with the outcome, no differences were found.

The usage of ECT with bleomycin coupled with surgery should be considered as a treatment option for canine STS especially as a limb sparing treatment when wide margin surgery and/or 
radiotherapy are not feasible. Moreover, ECT alone should be considered a treatment option for smaller STSs when other therapeutic strategies are not feasible and/or refused by the owner.

Further case-control studies are warranted to assess difference in efficacy and toxicity between ECT and other adjuvant treatments in marginally excised canine STSs. 


\section{Tables}

\begin{tabular}{|c|c|c|c|c|c|c|}
\hline Treatment & $\begin{array}{l}\text { Number } \\
\text { of cases }\end{array}$ & $\begin{array}{l}\text { Tumour } \\
\text { grade }\end{array}$ & $\begin{array}{c}\text { Histological } \\
\text { margins }\end{array}$ & $\begin{array}{c}\text { Recurrence } \\
\text { rate }\end{array}$ & $\begin{array}{c}\text { Disease-free } \\
\text { interval }\end{array}$ & Reference \\
\hline Marginal surgery & 35 & All grade I & $\begin{array}{l}31.6 \% \text { clean } \\
34.2 \% \text { clean } \\
\text { but close } \\
34.2 \% \text { dirty }\end{array}$ & $10.8 \%$ & $\begin{array}{l}\text { Median not } \\
\text { reached }\end{array}$ & $\begin{array}{l}\text { Stefanello et } \\
\text { al. (18) }\end{array}$ \\
\hline Surgery & 139 & $\begin{array}{l}51 \% \text { grade I } \\
42 \% \text { grade II } \\
7 \% \text { grade III }\end{array}$ & $\begin{array}{l}76 \% \text { clean } 24 \% \\
\text { clean but close }\end{array}$ & $\begin{array}{c}0 \% \text { if } \\
\text { completely } \\
\text { excised } \\
23 \% \text { if } \\
\text { marginally } \\
\text { excised }\end{array}$ & Not evaluated & $\begin{array}{l}\text { McSporran } \\
\text { (9) }\end{array}$ \\
\hline $\begin{array}{l}\text { Marginal or } \\
\text { radical surgery }\end{array}$ & 104 & Not indicated & $\begin{array}{l}33.7 \% \text { dirty } \\
18.3 \% \text { clean } \\
48.1 \% \\
\text { unknown } \\
\end{array}$ & $\begin{array}{c}27.9 \%(12 \% \\
\text { unknown) }\end{array}$ & Not evaluated & $\begin{array}{l}\text { Chase et al. } \\
\text { (21) }\end{array}$ \\
\hline $\begin{array}{l}\text { Wide surgery + } \\
\text { second intention } \\
\text { healing }\end{array}$ & 31 & $\begin{array}{l}77.4 \% \text { grade I } \\
22.6 \% \text { grade II }\end{array}$ & $100 \%$ clean & $3,2 \%$ & Not evaluated & $\begin{array}{l}\text { Prpich et al. } \\
\text { (19) }\end{array}$ \\
\hline $\begin{array}{l}\text { Marginal surgery } \\
+ \text { intralesional } \\
\text { cisplatin implants }\end{array}$ & 19 & $\begin{array}{l}42.1 \% \text { grade I } \\
52.6 \% \text { grade II } \\
5.3 \% \text { grade III } \\
\end{array}$ & Not evaluated & $16,6 \%$ & Not evaluated & $\begin{array}{l}\text { Havlicek et } \\
\text { al. (22) }\end{array}$ \\
\hline $\begin{array}{c}\text { Marginal surgery } \\
+ \text { Radiation } \\
\text { therapy }\end{array}$ & 56 & $\begin{array}{l}33 \% \text { grade I } \\
50 \% \text { grade II } \\
17 \% \text { grade III }\end{array}$ & $100 \%$ dirty & $18 \%$ & Not evaluated & $\begin{array}{l}\text { Demetriou } \\
\text { et al. (16) }\end{array}$ \\
\hline $\begin{array}{l}\text { Marginal surgery } \\
\text { + Metronomic } \\
\text { chemotherapy }\end{array}$ & $\begin{array}{l}85 \text { (30 treated } \\
\text { with } \\
\text { metronomic } \\
\text { chemotherap } \\
y+55 \\
\text { control })\end{array}$ & $\begin{array}{l}\text { Treated group: } \\
20 \% \text { grade I } \\
77 \% \text { grade II } \\
3 \% \text { grade III } \\
\\
\text { Control group: } \\
25 \% \text { grade I } \\
68 \% \text { grade II } \\
7 \% \text { grade III }\end{array}$ & $100 \%$ dirty & $\begin{array}{l}100 \% \text { in } \\
\text { control group } \\
\text { (treatment } \\
\text { group not } \\
\text { specified) }\end{array}$ & $\begin{array}{l}\text { Median DFI in } \\
\text { treated group not } \\
\text { reached; } \\
\text { Median DFI in } \\
\text { control group } \\
211 \text { days; } \\
\text { Predicted } \\
\text { minimum; } \\
\text { DFI for all dogs } \\
\text { 411 days } \\
\end{array}$ & $\begin{array}{l}\text { Elmslie et } \\
\text { al. (23) }\end{array}$ \\
\hline $\begin{array}{l}\text { Marginal or } \\
\text { incomplete } \\
\text { surgery }+ \\
\text { intralesional } \\
\text { cisplatin } \\
\text { impregnated } \\
\text { beads }\end{array}$ & 62 & $\begin{array}{c}76.5 \% \text { grade I } \\
15.7 \% \text { grade II } \\
7.9 \% \text { grade III } \\
\text { (data available in } \\
51 / 62 \text { dogs) }\end{array}$ & $\begin{array}{c}68.6 \% \text { dirty } \\
17.6 \% \text { clean } \\
\text { but close } \\
11.7 \% \\
\text { unknown } \\
\text { (data available } \\
\text { in } \\
51 / 62 \text { dogs) } \\
\end{array}$ & $\begin{array}{c}29 \% \\
\text { (data available } \\
\text { in 51/62 dogs) }\end{array}$ & $\begin{array}{l}\text { Median DFI not } \\
\text { reached } \\
\text { Median DFI for } \\
\text { grade } \\
\text { III tumours alone } \\
148 \text { days }\end{array}$ & $\begin{array}{l}\text { Bergman et } \\
\text { al. (24) }\end{array}$ \\
\hline $\begin{array}{c}\text { Hypofractionated } \\
\text { radiation therapy } \\
\text { on microscopic } \\
\text { disease }\end{array}$ & 48 & $\begin{array}{l}30 \% \text { grade I } \\
49 \% \text { grade II } \\
19 \% \text { grade III } \\
2 \% \text { not evaluated } \\
\end{array}$ & $\begin{array}{l}19 \% \text { clean but } \\
\text { close } \\
81 \% \text { dirty }\end{array}$ & Not specified & $\begin{array}{l}\text { Progression free } \\
\text { survival } 698 \\
\text { days }\end{array}$ & $\begin{array}{l}\text { Kung et al. } \\
\text { (25) }\end{array}$ \\
\hline $\begin{array}{l}\text { Orthovoltage } \\
\text { radiation therapy } \\
+ \text { low dose } \\
\text { doxorubicin on } \\
\text { microscopic } \\
\text { disease }\end{array}$ & 39 & $\begin{array}{c}37.5 \% \text { grade I } \\
22.5 \% \text { grade II } \\
7.5 \% \text { grade III } \\
32.5 \% \text { not } \\
\text { available }\end{array}$ & $100 \%$ dirty & $18 \%$ & $\begin{array}{l}\text { Median DFI } \\
213 \text { days }\end{array}$ & $\begin{array}{l}\text { Simon et } \\
\text { al. (14) }\end{array}$ \\
\hline $\begin{array}{l}\text { Primary re- } \\
\text { excision after } \\
\text { incomplete } \\
\text { resection }\end{array}$ & 41 & $\begin{array}{l}29 \% \text { grade I } \\
59 \% \text { grade II } \\
12 \% \text { grade III }\end{array}$ & $\begin{array}{c}95.2 \% \text { clean } \\
2.4 \% \text { clean but } \\
\text { close } \\
2.4 \% \text { dirty } \\
\end{array}$ & $15 \%$ & $\begin{array}{c}\text { Median DFI } \\
142 \text { days }\end{array}$ & $\begin{array}{l}\text { Bacon et } \\
\text { al. (13) }\end{array}$ \\
\hline
\end{tabular}

Table 1. List and summary description of the treatments proposed for canine STSs

Abbreviations: DFI, disease-free interval; STS, soft tissue sarcoma. 


\begin{tabular}{|cccc|}
\hline & $\begin{array}{c}\text { Group 1 (ECT alone) } \\
\mathbf{n = 4}\end{array}$ & $\begin{array}{c}\text { Group 2 (intraoperative } \\
\text { ECT) } \mathbf{n = 2 6}\end{array}$ & $\begin{array}{c}\text { Group 3 (adjuvant ECT) } \\
\mathbf{n}=\mathbf{2 4}\end{array}$ \\
$\begin{array}{c}\text { Tumour location } \\
\text { Limbs }\end{array}$ & 2 & 19 & 21 \\
Trunk & 1 & 5 & 1 \\
Head & 1 & 2 & 2 \\
Tumour size (cm) & & & \\
Median & 1.45 & 4.75 & 4.25 \\
Range & $1.0-5.0$ & $2.0-17.0$ & $0.4-14.0$ \\
Tumour grade & & & \\
I & N.A. & 8 & 13 \\
II & N.A. & 15 & 0 \\
III & N.A. & 2 & 4 \\
N.A. & & & 24 \\
Histological margins & & 11 & 0 \\
Incomplete & N.A. & 2 & 0 \\
Complete & N.A. & 13 & \\
N.A. & & & \\
\hline
\end{tabular}

Table 2. Parameters in the three groups of STSs treated with ECT as tumour location, size, grading and histological margins

Abbreviations: NA, not available; STS, soft tissue sarcoma; ECT, electrochemotherapy. Group 1 was censored from statistical analysis because of the small population collected.

a: $\chi 2$ test or Fisher's exact test, $\mathrm{P}>0.05$.

b: Mann-Whitney test, $\mathrm{P}>0.05$.

\begin{tabular}{|cccc|}
\hline & $\begin{array}{c}\text { Group 1 (ECT alone) } \\
\mathbf{n = 4}\end{array}$ & $\begin{array}{c}\text { Group 2 (intraoperative } \\
\text { ECT) } \mathbf{n}=\mathbf{2 6}\end{array}$ & $\begin{array}{c}\text { Group 3 (adjuvant ECT) } \\
\mathbf{n}=\mathbf{2 4}\end{array}$ \\
$\begin{array}{c}\text { Pulse frequency }(\mathbf{H z})^{\mathbf{a}} \\
1\end{array}$ & 3 & 8 & 8 \\
5000 & 1 & 18 & 16 \\
Amplitude to electric & & & \\
distance ratio $(\mathbf{V} / \mathbf{c m})^{\mathbf{a}}$ & 0 & 17 & 10 \\
1000 & 4 & 9 & 14 \\
1200 & & & \\
\end{tabular}

Table 3. Electrical parameters of ECT used in the three groups of STSs

Abbreviations: STS, soft tissue sarcoma; ECT, electrochemotherapy.

Eight cases were treated with Cytopulse PA4000 and 46 with Cytopulse Oncovet.

Group 1 was censored from statistical analysis because of the small population collected.

a: Fisher's exact test, $\mathrm{P}>0.05$. 


\begin{tabular}{|c|c|c|c|}
\hline & $\begin{array}{c}\text { Group } 1 \text { (ECT alone) } \\
n=4\end{array}$ & $\begin{array}{c}\text { Group } 2 \text { (intraoperative } \\
\text { ECT) } n=26\end{array}$ & $\begin{array}{c}\text { Group } 3 \text { (adjuvant ECT) } \\
n=24\end{array}$ \\
\hline \multicolumn{4}{|l|}{ Treatment response } \\
\hline $\mathrm{CR}$ & 2 & NA & NA \\
\hline PR & 1 & NA & NA \\
\hline SD & 1 & NA & NA \\
\hline PD & 0 & NA & NA \\
\hline \multicolumn{4}{|l|}{$\begin{array}{l}\text { Additional ECT } \\
\text { treatment }\end{array}$} \\
\hline Second & 2 & 2 & 1 \\
\hline Third & 1 & 1 & 1 \\
\hline Overall response rate & $75 \%$ & N.A. & NA \\
\hline $\begin{array}{l}\text { Follow-up (median and } \\
\text { range days) }\end{array}$ & $1113(837-2483)$ & $422.5(8-1297)$ & $596.5(16-2464)$ \\
\hline Median DFI (days) ${ }^{\text {b }}$ & NA & $81.5(26-1025)$ & $243(22-615)$ \\
\hline \multicolumn{4}{|l|}{ Patient outcome } \\
\hline Alive & 0 & 15 & 14 \\
\hline Death & 4 & 9 & 8 \\
\hline Unavailable & 0 & 1 & 1 \\
\hline $\begin{array}{l}\text { Overall tumour } \\
\text { recurrence rate }\end{array}$ & NA & $23.0 \%$ & $25.0 \%$ \\
\hline
\end{tabular}

Table 4. Treatment efficacy in the three groups of STSs treated with ECT

Abbreviations: CR, complete remission; PR, partial remission; SD, stable disease; PD, progressive disease; NA, not applicable; DFI, disease-free interval; STS, soft tissue sarcoma; ECT, electrochemotherapy.

Group 1 was censored from statistical analysis because of the small population collected. Group 2 and 3 included each one patient, which had two STS tumours.
a: Mann-Whitney test, $\mathrm{P}>0.05$.
$\mathrm{b}: \mathrm{t}$ test, $\mathrm{P}>0.05$. 


\begin{tabular}{|llccc|}
\hline $\begin{array}{l}\text { Amplitude to electric } \\
\text { distance ratio }\end{array}$ & Toxicity grade & $\begin{array}{c}\text { Group 1 (ECT } \\
\text { alone) } \mathbf{n}=\mathbf{4}\end{array}$ & $\begin{array}{l}\text { Group 2 } \\
\text { (intraoperative } \\
\text { ECT) } \mathbf{n}=\mathbf{2 6}\end{array}$ & $\begin{array}{c}\text { Group 3 (adjuvant } \\
\text { ECT) } \mathbf{n}=\mathbf{2 4}\end{array}$ \\
$1000 \mathrm{~V} / \mathrm{cm}^{*}$ & Grade 0 & 0 & 8 & 6 \\
& Grade 1 & 0 & 2 & 1 \\
& Grade 2 & 0 & 2 & 1 \\
& Grade 3 & 0 & 1 & 0 \\
$1200 \mathrm{~V} / \mathrm{cm}^{* *}$ & Grade 4 & 0 & 1 & 0 \\
& Grade 5 & 0 & 2 & 0 \\
& Grade 0 & 1 & 0 & 4 \\
& Grade 1 & 1 & 2 & 4 \\
& Grade 2 & 2 & 1 & 3 \\
& Grade 3 & 0 & 1 & 0 \\
\hline
\end{tabular}

Table 5. Toxicity grade in relation to the pulse voltage

Group 1 was censored from statistical analysis because of the small population collected.

Grade toxicity was divided into two groups: low toxicity group (grade $\leq 2$ ) and high toxicity group (grade $>2$ ).

Fisher's exact test $* \mathrm{P}>0.05, * * \mathrm{P}=0.0473$. 


\section{References}

1. Liptak J, Forrest L. Soft tissue sarcomas. In: Withrow SJ, Vail DM, Page RL, eds. Withrow \& MacEwen's Small Animal Clinical Oncology. 5th ed. St. Louis, MO: Elsevier Ltd; 2013: 356- 380.

2. Dennis MM, McSporran KD, Bacon NJ, Schulman FY, Foster RA, Powers BE. Prognostic factors for cutaneous and subcutaneous soft tissue sarcomas in dogs. Vet Pathol. 2011; 48(1): 73- 84.

3. Banks T, Straw R, Thomson M, Powers B. Soft tissue sarcomas in dogs: a study assessing surgical margin, tumour grade and clinical outcome. Aust Vet Pract. 2004; 34(4): 142- 147.

4. Ehrhart N. Soft-tissue sarcomas in dogs: a review. J Am Anim Hosp Assoc. 2005; 41(4): 241246.

5. Bray JP. Soft tissue sarcoma in the dog_part 1: a current review. J Small Anim Pract. 2016; 57(10): 510- 519.

6. Bray JP. Soft tissue sarcoma in the dog-Part 2: surgical margins, controversies and a comparative review. J Small Anim Pract. 2017; 58(2): 63- 72.

7. Avallone G, Boracchi P, Stefanello D, Ferrari R, Rebughini A, Roccabianca P. Canine perivascular wall tumors: high prognostic impact of site, depth, and completeness of margins. Vet Pathol. 2014; 51(4): 713- 721.

8. Trojani M, Contesso G, Coindre JM, et al. Soft tissue sarcomas of adults; study of pathological prognostic variables and definition of a histopathological grading system. Int $\mathbf{J}$ Cancer. 1984; 33(1): 37- 42.

9. McSporran KD. Histologic grade predicts recurrence for marginally excised canine subcutaneous soft tissue sarcomas. Vet Pathol. 2009; 46(5): 928- 933.

10. Bostock DE, Dye MT. Prognosis after surgical excision of canine fibrous connective tissue sarcomas. Vet Pathol. 1980; 17(5): 581- 588.

11. Kuntz C, Dernell W, Powers B, Devitt C, Straw R, Withrow S. Prognostic factors for surgical treatment of soft-tissue sarcomas in dogs: 75 cases (1986-1996). J Am Vet Med Assoc. 1997; 211(9): 1147- 1151.

12. Heller DA, Stebbins ME, Reynolds TL, Hauck ML. A retrospective study of 87 cases of canine soft tissue sarcomas, 1986-2001. Intern J Appl Res Vet Med. 2005; 3(2): 81- 87.

13. Bacon NJ, Dernell WS, Ehrhart N, Powers BE, Withrow SJ. Inadequate resection of soft tissue sarcomas. J Am Vet Med Assoc. 2007; 230(4): 3- 9.

14. Simon D, Ruslander DM, Rassnick KM, et al. Orthovoltage radiation and weekly low dose of doxorubicin for the treatment of incompletely excised soft-tissue sarcomas in 39 dogs. Vet Rec. 2007; 160(10): 321- 326.

15. Stefanello D, Avallone G, Ferrari R, Roccabianca P, Boracchi P. Canine cutaneous perivascular wall tumors at first presentation: clinical behavior and prognostic factors in 55 cases. J Vet Intern Med. 2011; 25(6): 1398- 1405.

16. Demetriou JL, Brearley MJ, Constantino-Casas F, Addington C, Dobson J. Intentional marginal excision of canine limb soft tissue sarcomas followed by radiotherapy. J Small Anim Pract. 2012; 53: 174- 181.

17. Cavanaugh R, Bacon N, Farese J, Dernell W, Ehrhart N, Withrow S. Local recurrence rate of canine soft-tissue sarcomas of the distal limbs treated by marginal excision alone. Paper 
presented at: Proceedings of the 27th Annual Conference of the Veterinary Cancer Society; Fort Lauderdale, FL. 2007:70.

18. Stefanello D, Morello E, Roccabianca P, et al. Marginal excision of low-grade spindle cell sarcoma of canine extremities: 35 dogs (1996-2006). Vet Surg. 2008; 37(5): 461- 465.

19. Prpich CY, Santamaria AC, Simcock JO, Wong HK, Nimmo JS, Kuntz CA. Second intention healing after wide local excision of soft tissue sarcomas in the distal aspects of the limbs in dogs: 31 cases (2005-2012). J Am Vet Med Assoc. 2014; 244(2): 187- 194.

20. Bray JP, Polton GA, Mcsporran KD, Bridges J, Whitbread TM. Canine soft tissue sarcoma managed in first opinion practice: outcome in 350 cases. Vet Surg. 2014; 43(7): 774- 782.

21. Chase D, Bray J, Ide A, Polton G. Outcome following removal of canine spindle cell tumours in first opinion practice: 104 cases. J Small Anim Pract. 2009; 50(11): 568- 574.

22. Havlicek M, Straw RS, Langova V, Dernell WS. Intra-operative cisplatin for the treatment of canine extremity soft tissue sarcomas. Vet Comp Oncol. 2009; 7(2): 122- 129.

23. Elmslie RE, Glawe P, Dow SW. Metronomic therapy with cyclophosphamide and piroxicam effectively delays tumor recurrence in dogs with incompletely resected soft tissue sarcomas. J Vet Intern Med. 2008; 22(6): 1373- 1379.

24. Bergman NS, Urie BK, Pardo AD, Newman RG. Evaluation of local toxic effects and outcomes for dogs undergoing marginal tumor excision with intralesional cisplatinimpregnated bead placement for treatment of soft tissue sarcomas: 62 cases (2009-2012). J Am Vet Med Assoc. 2016; 248(10): 1148- 1156.

25. Kung MBJ, Poirier VJ, Dennis MM, Vail DM, Straw RC. Hypofractionated radiation therapy for the treatment of microscopic canine soft tissue sarcoma. Vet Comp Oncol. 2016; 14(4): e135- e145.

26. Cancedda S, Marconato L, Meier V, et al. Hypofractionated radiotherapy for macroscopic canine soft tissue sarcoma: a retrospective study of 50 cases treated with a $5 \times 6$ Gy protocol with or without metronomic chemotherapy. Vet Radiol Ultrasound. 2016; 57(1): 75- 83.

27. Serša G, Miklavčič D, Čemažar M, Rudolf Z, Pucihar G, Snoj M. Electrochemotherapy in treatment of tumours. Eur J Surg Oncol. 2008; 34(2): 232- 240.

28. Miklavčič D, Mali B, Kos B, Heller R, Serša G. Electrochemotherapy: from the drawing board into medical practice. Biomed Eng Online. 2014; 13(29): 1- 20.

29. Froudarakis M, Hatzimichael E, Kyriazopoulou L, et al. Revisiting bleomycin from pathophysiology to safe clinical use. Crit Rev Oncol Hematol. 2013; 87(1): 90- 100.

30. Kelly JM, Belding BA, Schaefer AK. Acanthomatous ameloblastoma in dogs treated with intralesional bleomycin. Vet Comp Oncol. 2010; 8(2): 81- 86.

31. Marconato L, Buchholz J, Keller M, Bettini G, Valenti P, Kaser-Hotz B. Multimodal therapeutic approach and interdisciplinary challenge for the treatment of unresectable head and neck squamous cell carcinoma in six cats: a pilot study. Vet Comp Oncol. 2013; 11(2): $101-112$.

32. Čemazar M, Tamzali Y, Serša G, et al. Electrochemotherapy in veterinary oncology. J Vet Intern Med. 2008; 22(4): 826- 831. https://doi.org/10.1007/978-3-319-32886-7_107.

33. Markelc B, Serša G, Čemažar M. Differential mechanisms associated with vascular disrupting action of electrochemotherapy: intravital microscopy on the level of single normal and tumor blood vessels. PLoS One. 2013; 8(3): e59557.

https://doi.org/10.1371/journal.pone.0059557. 
34. Jarm T, Čemazar M, Miklavčič D, Serša G. Antivascular effects of electrochemotherapy: implications in treatment of bleeding metastases. Expert Rev Anticancer Ther. 2010; 10(5): 729- 746.

35. Calvet CY, Famin D, André FM, Mir LM. Electrochemotherapy with bleomycin induces hallmarks of immunogenic cell death in murine colon cancer cells. Oncoimmunology. 2014; 3(4): e28131-1- e28131-10.

36. Kodre V, Čemazar M, Pečar J, Serša G, Cor A, Tozon N. Electrochemotherapy compared to surgery for treatment of canine mast cell tumours. In Vivo. 2009; 23(1): $55-62$.

37. Spugnini EP, Vincenzi B, Citro G, Dotsinsky I, Mudrov T, Baldi A. Evaluation of cisplatin as an electrochemotherapy agent for the treatment of incompletely excised mast cell tumors in dogs. J Vet Intern Med. 2011; 25(2): 407- 411.

38. Lowe R, Gavazza A, Impellizeri JA, Soden DM, Lubas G. The treatment of canine mast cell tumours with electrochemotherapy with or without surgical excision. Vet Comp Oncol. 2017; 15(3): 775- 784.

39. Tozon N, Kodre V, Serša G, Čemažar M. Effective treatment of perianal tumors in dogs with electrochemotherapy. Anticancer Res. 2005; 25(2 A): 839- 846.

40. Čemažar M, Ambrožic Avgustin J, Pavlin D, et al. Efficacy and safety of electrochemotherapy combined with peritumoral IL-12 gene electrotransfer of canine mast cell tumours. Vet Comp Oncol. 2017; 15(2): 641- 654.

41. Tozon N, Lampreht Tratar U, Žnidar K, Serša G, Teissie J, Čemažar M. Operating procedures of the electrochemotherapy for treatment of tumor in dogs and cats. J Vis Exp. 2016;(116): 54760. https://doi.org/10.3791/54760

42. Spugnini EP, Vincenzi B, Citro G, et al. Electrochemotherapy for the treatment of squamous cell carcinoma in cats: a preliminary report. Vet J. 2009; 179(1): 117- 120. https://doi.org/10.1016/j.tvj1.2007.08.011.

43. Spugnini EP, Renaud SM, Buglioni S, et al. Electrochemotherapy with cisplatin enhances local control after surgical ablation of fibrosarcoma in cats: an approach to improve the therapeutic index of highly toxic chemotherapy drugs. J Transl Med. 2011; 9(1): 152. https://doi.org/10.1186/1479-5876-9-152.

44. Tozon N, Pavlin D, Sersa G, Dolinsek T, Cemazar M. Electrochemotherapy with intravenous bleomycin injection: An observational study in superficial squamous cell carcinoma in cats. J Feline Med Surg. 2014; 16(4): 291- 299. https://doi.org/10.1177/1098612X13507071.

45. Spugnini EP, Baldi A, Vincenzi B, et al. Intraoperative versus postoperative electrochemotherapy in high grade soft tissue sarcomas: a preliminary study in a spontaneous feline model. Cancer Chemother Pharmacol. 2007; 59(3): 375- 381. https://doi.org/10.1007/s00280-006-0281-y.

46. Tamzali Y, Borde L, Rols MP, Golzio M, Lyazrhi F, Teissie J. Successful treatment of equine sarcoids with cisplatin electrochemotherapy: a retrospective study of 48 cases. Equine Vet J. 2012; 44(2): 214- 220. https://doi.org/10.1111/j.2042-3306.2011.00425.x.

47. Tozon N, Kramaric P, Kos Kadunc V, Sersa G, Cemazar M. Electrochemotherapy as a single or adjuvant treatment to surgery of cutaneous sarcoid tumours in horses: a 31-case retrospective study. Vet Rec. 2016; 179: 627. https://doi.org/10.1136/vr.103867.

48. Racnik J, Svara T, Zadravec M, et al. Electrochemotherapy with bleomycin of different types of cutaneous tumours in a ferret (Mustela putorius furo). Radiol Oncol. 2018; 52(1): 98- 104. https://doi.org/10.1515/raon-2017-0057.

49. Lanza A, Pettorali M, Baldi A, Spugnini EP. Surgery and electrochemotherapy treatment of incompletely excised mammary carcinoma in two male pet rats (Rattus norvegicus). J Vet Med Sci. 2017; 79(3): 623- 625. https://doi.org/10.1292/jvms.16-0578. 
50. Spugnini EP, Vincenzi B, Citro G, et al. Adjuvant electrochemotherapy for the treatment of incompletely excised spontaneous canine sarcomas. In Vivo (Brooklyn). 2007; 21(5): 819822.

51. Spugnini EP, Vincenzi B, Betti G, et al. Surgery and electrochemotherapy of a high-grade soft tissue sarcoma in a dog. Vet Rec. 2008; 162(6): 186- 188. https://doi.org/10.1136/vr.162.6.186.

52. Mir LM, Gehl J, Sersa G, et al. Standard operating procedures of the electrochemotherapy: instructions for the use of bleomycin or cisplatin administered either systemically or locally and electric pulses delivered by the CliniporatorTM by means of invasive or non-invasive electrodes. Eur J Cancer. 2006; 4(11): 14- 25. https://doi.org/10.1016/j.ejcsup.2006.08.003.

53. Therasse P, Arbuck SG, Eisenhauer EA, et al. New guidelines to evaluate the response to treatment in solid tumors. J Natl Cancer Inst. 2000; 92: 205- 216.

54. Mir LM. Bases and rationale of the electrochemotherapy. Eur J Cancer. 2006; 4(11): 38- 44. 